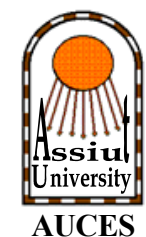

\title{
STUDIES ON Fe, Mn, Ni AND Pb LOAD ON SOIL AND ITS ENRICHMENT FACTOR RATIOS IN DIFFERENT SOIL GRAIN SIZE FRACTIONS AS AN INDICATOR FOR SOIL POLLUTION
}

\author{
F. H. Rabie and M. F. Abd El-Sabour \\ Soil Department, Faculty of Agriculture, Ain Shams University \\ Soil and Water Pollution Unit, Nuclear Research Center, Egypt
}

\begin{abstract}
:
An industrial area north of greater Cairo was selected to investigate the impact of intensive industrial activities on soil characteristics and $\mathrm{Fe}, \mathrm{Mn}, \mathrm{Ni}$ and $\mathrm{Pb}$ total contents. The studied area was divided into six sectors according to its source of irrigation water and/or probability of pollution. Sixteen soil profiles were dug and soil samples were taken, air dried, fractionated to different grain size fractions, then total heavy metals ( $\mathrm{Fe}, \mathrm{Mn}, \mathrm{Ni}$ and $\mathrm{Pb}$ ) were determined using ICP technique. The enrichment factor for each metal for each soil fraction/soil layer was estimated and discussed.

The highest $\mathrm{EF}$ ratio in the clay fraction was mainly with $\mathrm{Pb}$ which indicates the industrial impact on the soil. In case of sand fraction, Mn was the highest when compared with other studied metals. Concerning silt fraction, a varied accumulation of $\mathrm{Fe}, \mathrm{Mn}$ and Pb was observed with soil depth and different soil profiles.
\end{abstract}

\section{INTRODUCTION :}

The cycle of elements in nature is limited on earth and life has adopted itself to it. Naturally, the concentrations of undesired elements both in the soil solution and in natural waters is low. This situation may change drastically when the content of available harmful elements in soil is increased by several orders of magnitude in industrial areas. Based on the characteristics of soil, i.e., its large volume, buffering 
capacity and biological activity, not every enrichment of the soil is to be considered as pollution. The concept of soil pollution must be restricted to accumulation of heavy metals at a reactive level which is toxic to living soil organisms and harming the plant production [1]. Soil pollution may occur as a consequence of diff-erent types of input of unwanted substances such as sewage sludge applications, irrigation with polluted wastewater, pesticides and intensive fertilization.

Abdel Kareim [2] reported that the average value of total $\mathrm{Fe}$ in alluvial soils of Monofia Governorate was $4.7 \%$. Concerning the total content of $\mathrm{Fe}$ in contaminated alluvial soils, Rabie [3] reported that the highest value was $16.6 \%$ in the surface layer of alluvial soils at El-Saff region due to the irrigation with liquid industrial wastes.

Manganese is not distributed uniformly in soil substrata and, in addition to various nodules, is known also, to be concentrated at certain spots which are usually enriched with several trace elements. Although Mn can be concentrated in various soil horizons, particularly in those enriched with $\mathrm{Fe}$ oxides or hydroxides, usually this element is also accumulated in top soils as the result of its fixation by organic matter. Manganese toxicity symptoms have observed in a wide range of crops, including soybean, cotton, tobacco and upland rice grown on soils with high available Mn. Reported toxic concentrations for Mn ranged from 80 to $5000 \mathrm{mg} / \mathrm{kg}$ soil [4]. In Egypt, Rashad [5] found that the content of total Mn in the normal alluvial soils of Delta ranged between 720 and $1080 \mathrm{ppm}$ with an average of 926 ppm. Concerning the total $M n$ in contaminated alluvial soils of Egypt, Rabie [3] reported that the highest value (2550 ppm) was observed in the surface layer of alluvial soils at El-Saff area due to irrigation with liquid industrial wastes. El-Leithi [6] found that the total content of $\mathrm{Mn}$ in contaminated alluvial soils of Delta ranged between 515.2 to $1341.1 \mathrm{ppm}$. El-Sebaay [7] found that the values of both total and available $\mathrm{Mn}$ were increased by irrigation with wastewater.

Lead is found in uncontaminated soils at concentrations $<\mathbf{2 0 . 0} \mathbf{m g} / \mathbf{k g}$. Much higher concentrations have been reported in many areas as a consequence of anthropogenic emissions, (often over many years). Nriagu [8] reported a mean of $17.0 \mathrm{mg} \mathrm{Pb} / \mathrm{kg}$ soil, while, Davies [9] reported that the normal $\mathbf{P b}$ content in uncontaminated soils was about 40 $\mathrm{mg} / \mathrm{kg}$. In Egypt, Rashad [5] found that the normal level of $\mathrm{Pb}$ in the alluvial soil of Nile Delta ranged between 32.0 and $48.0 \mathrm{ppm}$ with an average of $41.0 \mathrm{ppm}$ for total content. ElSabbagh [10] found that the total content of $\mathrm{Pb}$ in the surface layer of the soil ranged between 17.0 and $48.0 \mathrm{ppm}$ with an average of $29.0 \mathrm{ppm}$. Ramadan [11] reported that the total content of $\mathrm{Pb}$ ranged between 84.4 and $101.1 \mathrm{ppm}$ with an average of $92.8 \mathrm{ppm}$ in polluted alluvial soils.

Recently, nickel has become a serious pollutant element that released in the emissions from metal processing operations 
and from the combustion of coal and oil [4]. The average concentration of $\mathrm{Ni}$ in world soils is probably $20.0 \mathrm{mg} / \mathrm{kg}$, which obscures much variation between soil types. The application of sludges and certain phosphate fertilizers also may be important sources for Ni. In particular, Ni in sewage sludge, that is present mainly in organic chelated forms, is readily available to plants and therefore may be highly phytotoxic. In Egypt, Rashad [5] found that the normal level of total $\mathrm{Ni}$ in alluvial soils of Nile Delta ranged between 21.0-44.0 ppm (average $32.0 \quad \mathrm{ppm}$ ). Concerning contaminated alluvial soils of Egypt, El-Sayed and Hegazy [12] reported that the total content of $\mathrm{Ni}$ in contaminated alluvial soils of El-Fayoum Governorate ranged between 33.5 and 77.0 with an average of $55.3 \mathrm{ppm}$. The goal of this study is to investigate the effect of industrial wastewater on soil pollution and heavy metals accumulation in the soil profile.

\section{MATERIALS AND METHODS :}

The studied area was divided into six sectors according to the source of irrigation water and the probability of pollution with organic and inorganic wastes (Fig 1). Sixteen soil profiles were dug and soil samples were taken from different layers. Another soil samples were taken from a virgin soil at the vacinity to represent uncultivated control soil (Group A) which is represented by soil profile No. 1 .

Sector B : the source of irrigation water for the soils of this sector is regular fresh water from El-Boulaqeyah canal which is located far from the pollution sources of the studied area. These soils are considered non-polluted and are taken as control. Profile No. 2 represents this sector.

Sector C: The soils of this sector are subjected to irrigation with heavily polluted wastewater from Shebin El-Qanater collector, profile No.3 represents these soils.

Sector D: These soils are located at the downstream of El-Shaboura canal, so it subjected to be irrigated with polluted water (site 6 and 7 at the end of the canal). Soil profile No. 4 represents these soils.

Sector E: The soils of this sector are subjected to be irrigated with combination of El-Shaboura canal water and either Mostorod collector wastewater (Profiles No. $5,6,7)$ or Shebin El-Qanter collector wastewater (Proffiles No. 8, 9, 10).

Sector F : These soils are subjected to be irrigated from El-Boulaqeyah canal water and Laza agricultural drain wastewater (profiles, No. 11, 12, 13, 14 and 15).

Sector G: The source of irrigation water for the soils of this sector is heavily polluted wastewater of Mostorod collector (Profile No. 16).

\section{Soil analyses :}

Disturbed soil samples were collected from different layers of the studied soil profiles. These samples were air-dried, crushed, ground by wood rod and sieved through $2 \mathrm{~mm}$ sieve. Fractions below 2 
mm were maintained and stored in plastic bottles for physical and chemical determinations. Pipette method [13] was used for the determination of the soil fractions. Different grain size fractions (<2 $\mu$ "clay", 2-50 $\mu$ "silt", and 50-2000 $\mu$ "sand") were separated by sedimentation and decantation. Total contents of Fe, Mn, $\mathrm{Pb}$ and $\mathrm{Ni}$, either in the whole soil sample or in the different soil fractions were extracted by wet digestion of $1.0 \mathrm{~g}$. sample with $\mathrm{HF} / \mathrm{HClO}_{4}[14]$ and using the heavy metals were measured Ion coupled plasma (ICP).

\section{RESULTS AND DISCUSSIONS :}

In this work, the total heavy metals were determined in some selected soil samples and in different grain size fractions of these samples to asses their accumulation and movement in soil.

\section{Total Fe:}

The amount of total iron in the investigated soils ranged between 3.82 $7.68 \%$. The data of table 1 show that the total amount of $\mathrm{Fe}$ in the uncultivated control soil (A) ranged between 3.82 and $3.81 \%$, while in the cultivated control soil $B$ and subjected to the irrigation with fresh water of El-Boulaqeyah canal ranged between 3.81 and $3.92 \%$. Using irrigation with wastewater for increased total Fe from $3.82 \%$ in the surface layer of uncultivated control soil (A) to 7.68, 6.65 and $6.01 \%$ in the soils of group $C$ (subjected to be irrigated with wastewater of Shebin El-Qanater collector), D (subjected to irrigation with polluted water of El-Shaboura canal) and $G$ (subjected to be irrigated with wastewater of Mostorod collector), respecively. As previously mentioned, the total Fe in the wastewater of Shebin ElQanater collector, polluted water of ElShaboura canal and wastewater of Mostorod collector are fairly high to about 14046, 4643 and $12551 \mu \mathrm{g} / \mathrm{L}$, respectively, $[15,16]$. Therefore, there is no doubt that the high contents of Fe in the investigated soils resulted from using such polluted waters for irrigation. ElSebaay[7] reported indicated that using waste-water for irrigation increased markedly the total $F e$ in the surface layers of agricultural soils of Egypt to 4.0-8.7\%. Concerning the distribution of total Fe in investigated soils, it is clear from Table (1) that irrigation by wastewater tends to increase total Fe up to about $60 \mathrm{~cm}$ depth. Generally, the highest values of total Fe were observed in the surface layers of the soils of groups C, D and G (6.01-7.68\%) which were decreased with depth (4.80-4.86\%).

\section{Distribution of Fe between differ- ent grain size fractions:}

The amount of total $\mathrm{Fe}$ in different grain size fractions (Clay, silt and sand) in different layers of investigated soils are given in Table (2). The data shows that the clay fraction has the highest 
amount of $\mathrm{Fe}$ in all investigated soils. In both uncultivated control soil (A) and cultivated control soil B (irrigated with fresh water of El-Boulaqeyah canal), Fe contents in the three fractions ranged between $(4.34$ and $5.02 \%)$ for clay fraction, $(3.52-4.83 \%)$ for silt fraction and (1.48-1.94\%) for sand fraction.

Concerning investigated soils irrigated with lower water qualities, the fractions of surface layer of the soils of groups D (irrigated with polluted water of ElShaboura canal) and $G$ (irrigated with wastewater of Mostorod collector) have the highest levels of Fe. Where, clay fraction has $6.89-7.94 \%$, silt has 6.19$6.61 \%$ and sand has $3.25-3.77 \%$. Rabie [3] reported that the distribution of $\mathrm{Fe}$ in grain size fractions of alluvial soils at Helwan-El-Saff area was as follows: Clay $>$ Silt $>$ Sand. On the other hand, it seems from the distribution of $\mathrm{Fe}$ in the different grain size fractions of cultivated control soil B (irrigated with fresh water of El-Boulaqeyah canal) and the soils of groups $C, E$ and $F$ (irrigated with wastewater) that there is no observed differences between these soils (Table 2). The distribution of total $\mathrm{Fe}$ in the different fractions of these soils, mostly, exhibit similar trend. This is due to that these soils are derived from the same origin (recent alluvial deposits), in the same time. The amounts of $\mathrm{Fe}$ added from irrigation wastewater are relatively small in countered with the initial content of $\mathrm{Fe}$ in the soil.

\section{Total Mn:}

Table (1) show that the total amounts of $M n$ in the uncultivated control soil (A) ranged between 865 and 915 ppm, while in the cultivated control soil (B) it ranged between 981 and $1150 \mathrm{ppm}$. The normal Mn levels in the agricultural alluvial soils of Egypt was reported to be in the range from 720 to $1080 \mathrm{ppm}$ with an average mean of 926 ppm. El-Toukhy [17] found that the total content of $M n$ in agricultural alluvial soil North Nile Delta ranged between 483 and $976 \mathrm{ppm}$ with an average of $730 \mathrm{ppm}$.

The highest values of total Mn were observed in the surface layers of both groups D (subjected to irrigation with polluted water of EL-Shaboura canal) and $C$ (subjected to irrigation with wastewater of Shebin EL-Quanater collector), as they were 1677 and 1624 ppm, respectively. A significant $\mathrm{Mn}$ enrichment was observed in the subsurface layers of groups $C, D$ and $G$ (subjected to irrigation with wastewater). It seems from this data that irrigation with wastewater tend to increase Mn content in these soils compared with the uncultivated (A) and cultivated (B) control soils. The distribution of the total Mn through the soil profile varied due to different conditions of each tested soil (cultivation, type of irrigation water and its Mn content, as well as other specific factors). 


\section{Distribution of Mn between the different grain size fractions:}

Manganese distribution behavior showed various patterns of distribution for the different size fractions from one profile to another. In both, uncultivated and cultivated control soils (A \& B), the average values of total $M n$ in the three fractions clay, silt and sand are (4281134 ppm), (792-1626 ppm) and (405$1430 \mathrm{ppm})$, respectively. Concerning the investigated soils (subjected to irrigation with wastewater), the average mean values of total $\mathrm{Mn}$ in these fractions are 914.6, 897.5 and 2130.7 ppm, respectively. Generally, as is shown in Table (2), calculating the relative contribution of different fractions to the total Mn content indicated, that the sand fraction has the highest ratio (38.7-41.6\%) followed by silt fraction (28.6-38.2\%) and clay fraction (23.1-29.8\%). Increments in Mn content in the coarser fraction is probably due to the formation of hydrated Mn oxides of sizes greater than that of clay fraction [18]. Also, precipitation of Mn compounds on particle surfaces of coarser fractions might be more persistent and the formation of Mn-nodules may occur. However when the soil samples are ground, these formations may be disintegrated into fragments of the same size as the coarser grain fractions.

\section{A- Total Pb :}

Total amounts of $P b$ in the studied soils are given in Table (1). The amount of total $P b$ in the uncultivated control soil (A) seems to be higher (between 66.0 and 70.6 ppm with an average of 68.3 ppm) than previous reported levels for soils. While in cultivated control soil $B$ (irrigated with fresh water), its range between 68.1 and $72.0 \mathrm{ppm}$ with an average of $\mathbf{7 4 . 0}$ ppm. Rashad [5] reported that the normal level of total $P b$ in the alluvial soils of Nile Delta ranges between 32.0 and $48.0 \mathrm{ppm}$ with an average of $40.0 \mathrm{ppm}$. These results may suggest precipitation of air suspended particulates emmited from several smelters in the nearby area. Concerning the investigated soils subjected to be irrigated with wastewater, the amount of total $P b$ in the surface layers are noticably higher than those of the control soils (A and $B$ ). Thus, the highest values were obtained in the surface layers of soils of groups $\mathrm{C}$ (irrigated with wastewater of Shebin El-Qanater collector), D (irrigated with polluted water of El-Shaboura canal) and $G$ (irrigated with wastewater of Mostorod collector). These values are $233.0,184.0$ and 180.0 ppm respectively which are higher than those of uncultivated control soil (A) by 3.3, 2.6 and 2.5, respectively. As shown in Table (2), the amount of total $\mathrm{Pb}$ decreases with depth as the total $P b$ in the deepest layers of these soils $(C$, $D$ and $G$ ) are $109.0,102.0$ and $145.8 \mathrm{ppm}$, 
respectively. Similar results were obtained by El-Sabbagh and Ramadan $[10,11]$. The reported that total content of $\mathrm{Pb}$ increased up to about $101.1 \mathrm{ppm}$ in the surface layer of these soils (Mostorod area) this is due to industrial activities and irrigation with polluted water of EIShaboura canal and wastewater of Mostorod collector. Rabie [3] recorded 129.0-189.0 ppm for total $P b$ in the surface layers of the alluvial soils at Helwan El-Saff area. They attributed due to the increase of the total and the available $P b$ in these soils to, both, industrial activities and irrigation with wastewater.

Distribution of $\mathrm{Pb}$ between the different grain size fractions:

The total amount of $\mathrm{Pb}$ in the different grain size fractions of the investigated soils are given in Table (2). The data show that the different fractions in both uncultivated (A) and cultivated (B) control soils, have an average of (94.7-105.13 ppm), (51.3-89.6 ppm) and (7.3-16.8 ppm) in the clay, silt and sand fractions, respectively. Concerning contaminated soils $(C, D$ and G), the three fractions clay, silt and sand contain (188.5-298.0 ppm), (178.0-198.8 ppm) and (11.5-64.2 ppm), respectively. It is clear that the clay has the highest content of $\mathrm{Pb}$ which is about 7-9 times the sand fraction. The data in Table (2) indicates that clay fraction contributes with 46.4-52.1 \% of the total $\mathrm{Pb}$, while silt fraction has $39.9-40.4$ and sand fraction with $7.5-13.7 \%$, which is this confirmed by the previous studies [19].

\section{Total Ni:}

Total amounts of $\mathrm{Ni}$ in the investigated soils are given in Table (1). The amount of total $\mathrm{Ni}$ in the uncultivated control soil (A) ranges between 40.8 and $43.8 \mathrm{ppm}$, while in the cultivated control soil (B) ranges between 52.0 and $67.0 \mathrm{ppm}$. Rashad [5] reported that the amount of total $\mathrm{Ni}$ in nonpolluted alluvial soils of Nile Delta ranges between 21.0 and $44.0 \mathrm{ppm}$ with an average of $32.0 \mathrm{ppm}$. Concerning the investigated soils which were, subjected to be irrigated with different wastewater sources, the data show that the highest values of total $\mathrm{Ni}$ were obtained in the surface layers of soils of groups $C$ (irrigated with wastewater of Shebin ElQanater collector) and D (irrigated with polluted water of El-Shaboura canal) which are 177.0 and $98.0 \mathrm{ppm}$, respectivily while the total amount of $\mathrm{Ni}$ in the deepest layers of the same soils are $\mathbf{1 1 2 . 0}$ and $83.0 \mathrm{ppm}$, respectively. These values reflect the effect of irrigation with wastewater of Shebin El-Qanater collector and polluted water of ElShaboura canal (which have an average value of about 314 and $62.5 \mu \mathrm{g} / \mathrm{L} \mathrm{Ni}$, respectively, as indicated by AbdelSabour [15]. 


\section{Distribution of $\mathrm{Ni}$ between different grain size fractions:}

The amount of $\mathrm{Ni}$ in the different grain size fractions of studied soils are given in Table (2). The data show that the different fractions in both uncultivated (A) and cultivated (B). Control soils have an average of (63.7-77.7 $\mathrm{ppm}),(31.0-74.0$ ppm) and (9.8-12.8 ppm) in the clay, silt and sand fractions respectively. Also, data in Table (2) indicate that clay fraction contributes with $53.8-54.0 \%$ of the total Ni while silt fraction with 37.3 $38.4 \%$ and sand fraction with $\mathbf{7 . 6 - 8 . 9 \%}$. Concerning the investigated soils subjected to irrigation with wastewater from different sources. The data show that $\mathrm{Ni}$ content in the surface layers increased markedly compared with control soils. Soils of group $C$ have the highest values of $\mathrm{Ni}$ content in the three fractions, where clay has $280.0 \mathrm{ppm}$, silt has 180.0 ppm and sand has $18.8 \mathrm{ppm}$. It is clear that the enrichment of $\mathrm{Ni}$ in the clay fraction is about 10 times the sand fraction. Data in Table (2) indicate that clay fraction contributes (unpolluted soil) with $50.9-52.5 \%$ of the total $\mathrm{Ni}$ while silt fraction with $40.9 \%$ and sand fraction with $6.6-8.2 \%$.

\section{Enrichment factor of heavy metals in different grain size fractions:}

A number of authors have fractionated soil in order to determine the relative contributions of clay, silt and sand in heavy metal content of a certain soil. Rabie [20] found that $\mathrm{Zn}, \mathrm{Co}, \mathrm{Cu}$ and $\mathrm{Cd}$ are bound up in the clay and /or silt fractions. Total metal content of the soil and metal content of each fraction were used to calculate the enrichment factor for each fraction at different soil layers according to Davies [9].

Table (3) showed that enrichment factor of heavy metals in different soil fractions of different soil layers (studied soil profiles) as affected by different wastewater, used for irrigation. The enrichment of $\mathrm{Fe}$ in clay fraction is about 3-4 times the sand fraction. This is due to captured that $\mathrm{Fe}$ can be captured in the octahedral positions of clay interlatices, in addition to the formation of $\mathrm{Fe}$ hydrated oxides which often precipitate between the inter surfaces of silicate minerals [21].

The presented data indicate that clay fraction is enriched in most heavy metals compared with other soil grades, particularly in surface layers $(0-15 \mathrm{~cm})$ except in case of $M n$ which tends to accumulate in the sand fraction. These results agree with those obtained by Nair and Cottenie [19]. Concerning Ni, calculated EF indicate that this metal was always associated with the clay fraction in all layers of the investigated soil profiles. It is worth to mention that the increase of EF- values with soil depth, in some cases, may suggest that some heavy 
metals in the contaminated soils are mobile and reachable through the soil profile due to the presence of organic complexes usually found in wastewater effluent. These dissolved organic compounds act as a chelating agents and protect metals from the ordinary precipitation and fixation process in arid soils. This trend confirms other data reported for $\mathrm{Cd}, \mathrm{Zn}, \mathrm{Co}$ and $\mathrm{Cu}[20]$.

\section{CONCLUSION :}

In conclusion, continuos irrigation with wastewater has a marked increase on the amount of heavy metals in the surface layers of the studied area. It is clear that the highest $E F$ ratios in the clay fraction was mainly with $P b$ which indicates the industrial impact on the soil. In case of sand fraction, Mn was the highest always compared with other studied metals. Concerning silt fraction, a varied accumulation of $\mathrm{Fe}, \mathrm{Mn}$ and $\mathrm{Pb}$ was observed with soil depth and different soil profiles.

Table (1): Soil fractions \% and total content of $\mathrm{Fe}, \mathrm{Mn}, \mathrm{Pb}$ and $\mathrm{Ni}$ in the investigated soils.

\begin{tabular}{|c|c|c|c|c|c|c|c|c|}
\hline \multirow{2}{*}{$\begin{array}{l}\text { Profile } \\
\text { groups }\end{array}$} & \multirow{2}{*}{$\begin{array}{l}\text { Soil depth } \\
\text { (cm) }\end{array}$} & \multicolumn{3}{|c|}{$\%$} & \multicolumn{4}{|c|}{ Total heavy metals $(\mu \mathrm{g} / \mathrm{g})$} \\
\hline & & clay & silt & Sand & $\mathbf{F e}$ & Mn & $\mathbf{P b}$ & $\mathbf{N i}$ \\
\hline \multirow[t]{3}{*}{$\mathbf{A}$} & $0-15$ & 45.8 & 31.5 & 20.0 & 38200 & 915 & 70.6 & 43.5 \\
\hline & $15-30$ & 43.8 & 35.5 & 19.5 & 38800 & 880 & 68.5 & 43.8 \\
\hline & $30-60$ & 39.5 & 41.2 & 18.0 & 38600 & 865 & 66.0 & 40.8 \\
\hline \multirow{4}{*}{ B } & $0-15$ & 34.8 & 32.0 & 28.2 & 38100 & 981 & 72.0 & 52.0 \\
\hline & $15-30$ & 47.0 & 35.2 & 32.5 & 39200 & 1150 & 68.1 & 67.0 \\
\hline & $30-60$ & 33.0 & 26.8 & 28.0 & 43500 & 1012 & 70.4 & 60.0 \\
\hline & 0-15 & 55.6 & 23.5 & 18.0 & 76800 & 1624 & 233 & 177 \\
\hline \multirow{4}{*}{$\mathbf{C}$} & $15-30$ & 62.2 & 29.3 & 6.2 & 68200 & 1499 & 169 & 102 \\
\hline & $30-60$ & 70.4 & 25.9 & 3.4 & 49500 & 1200 & 109 & 112 \\
\hline & $0-15$ & 70.9 & 22.9 & 3.5 & 66500 & 1677 & 184 & 98 \\
\hline & $15-30$ & 72.6 & 21.7 & 5.1 & 59200 & 1477 & 164 & 81 \\
\hline \multirow[t]{3}{*}{ D } & $30-60$ & 75.9 & 23.2 & 1.0 & 48006 & 1342 & 102 & 83 \\
\hline & $0-15$ & 64.7 & 28.9 & 20.7 & 46540 & 1136 & 162 & 77.8 \\
\hline & $15-30$ & 49.1 & 24.6 & 21.3 & 45740 & 1051 & 140 & 77.5 \\
\hline \multirow{4}{*}{$\mathbf{E}$} & $30-60$ & 49.0 & 27.0 & 17.5 & 45750 & 981 & 95.3 & 78 \\
\hline & $0-15$ & 52.3 & 28.3 & 15.7 & 43500 & 1280 & 111.8 & 75.4 \\
\hline & $15-30$ & 49.6 & 31.6 & 16.5 & 45050 & 1438 & 89.6 & 67 \\
\hline & $30-60$ & 54.0 & 25.2 & 15.1 & 48125 & 982 & 86.1 & 68.6 \\
\hline \multirow[t]{3}{*}{$\mathbf{F}$} & $0-15$ & 33.2 & 33.7 & 26.8 & 60100 & 985 & 180.1 & 51 \\
\hline & $15-30$ & 34.7 & 31.5 & 25.2 & $\mathbf{5 8 2 0 0}$ & 1205 & 169.7 & 46 \\
\hline & $30-60$ & 45.5 & 31.9 & 14.8 & 58000 & 1181 & 145.8 & 31 \\
\hline G & & & & & & & & \\
\hline
\end{tabular}


Ass. Univ. Bull. Environ. Res. Vol. 2 No. 2, October 1999

$-20-$ 
Ass. Univ. Bull. Environ. Res. Vol. 2 No. 2, October 1999

Fig. (1) : Location of water samples and soil profiles (1-16) .

- Canals water samples.

- Collectors waster water samples. $\boldsymbol{\nabla}$ Factories outlet samples.

(C) Sewage and domestic wastes samples.

Table (2) Distribution of tested metals ( $\mu \mathrm{g} / \mathrm{g}$ fraction) between various particle size fractions in investigated soils.

\begin{tabular}{l|l|c|c|c|c|c|c|c|c}
\hline \hline \multirow{2}{*}{$\begin{array}{l}\text { Profile } \\
\text { groups }\end{array}$} & & \multicolumn{4}{|c|}{ Soil layer $\mathbf{0}-15 \mathrm{~cm}$} & \multicolumn{4}{c}{ Soil layer 15-30 cm } \\
\cline { 3 - 8 } & & $\mathrm{Fe}$ & $\mathrm{Mn}$ & $\mathrm{Pb}$ & $\mathrm{Ni}$ & $\mathrm{Fe}$ & $\mathrm{Mn}$ & $\mathrm{Pb}$ & $\mathrm{Ni}$ \\
\hline & & & & & & & & & \\
\hline
\end{tabular}


Ass. Univ. Bull. Environ. Res. Vol. 2 No. 2, October 1999

\begin{tabular}{|c|c|c|c|c|c|c|c|c|c|}
\hline \multirow[t]{4}{*}{$\mathbf{A}$} & Clay & 44633 & 691 & 105 & 64.9 & 43436 & 1134 & 101 & 63.7 \\
\hline & Silt & 35400 & 980 & 54.5 & 35.6 & 35200 & 792 & 51.3 & 31.3 \\
\hline & Sand & 14772 & 936 & 16.8 & 9.8 & 14980 & 405 & 14.7 & 10.6 \\
\hline & Clay & 50298 & 428 & 113.1 & 74.6 & 51085 & 993 & 94.7 & 77.7 \\
\hline \multirow[t]{4}{*}{ B } & Silt & 47407 & 1626 & 85.9 & 67.8 & 43611 & 810 & 89.6 & 74.0 \\
\hline & Sand & 27040 & 995 & 7.3 & 10.0 & 16950 & 1430 & 8.15 & 12.8 \\
\hline & Clay & 51072 & 837 & 268 & 280 & 51203 & 811 & 118 & 105 \\
\hline & Silt & 42406 & 1119 & 252 & 180 & 47639 & 922 & 105 & 94 \\
\hline \multirow[t]{4}{*}{ C } & Sand & 35002 & 2555 & 30.5 & 18.8 & 31718 & 3176 & 120 & 16.5 \\
\hline & Clay & 50600 & 1369 & 188.5 & 108.5 & 50500 & 1199 & 183.1 & 89.9 \\
\hline & Silt & 44543 & 1480 & 198.8 & 80.1 & 49900 & 1359 & 98.1 & 62.2 \\
\hline & Sand & 22500 & 2880 & 11.5 & 14.8 & 20400 & 2537 & 7.0 & 8.8 \\
\hline \multirow{3}{*}{ D } & Clay & 52591 & 52591 & 729 & 215.5 & 50670 & 700 & 91.7 & 114 \\
\hline & Silt & 49201 & 49201 & 925 & 325 & 49037 & 839 & 113.3 & 188 \\
\hline & Sand & 31090 & 31090 & 2237 & 79.0 & 33943 & 3069 & 40.9 & 15.3 \\
\hline \multirow{4}{*}{$\mathbf{E}$} & Clay & 54421 & 1199 & 116.8 & 83 & $\mathbf{5 8 3 7 8}$ & 860 & 101.2 & 82.3 \\
\hline & Silt & 40100 & 1496 & 98.5 & 70.2 & 42700 & 1429 & 90.2 & 64.5 \\
\hline & Sand & 20100 & 1180 & 14.8 & 5.2 & 22800 & 900 & 8.6 & 2.8 \\
\hline & Clay & 79433 & 707 & 298 & 119 & 69495 & 735 & 170.7 & 37.4 \\
\hline \multirow{2}{*}{$\mathbf{F}$} & Silt & 66132 & 723 & 178 & 71.3 & 62113 & 1188 & 157.5 & 31.6 \\
\hline & sand & 37679 & 1047 & 64.2 & 16.5 & 30300 & 1726 & 79.5 & 14.5 \\
\hline G & & & & & & & & & \\
\hline
\end{tabular}


Table (3) Enrichment factors for selected heavy metals between various particle size fractions in investigated soils.

\begin{tabular}{|c|c|c|c|c|c|c|c|c|c|}
\hline \multirow{2}{*}{$\begin{array}{c}\text { Profile } \\
\text { groups }\end{array}$} & & \multicolumn{4}{|c|}{ Soil layer $0-15 \mathrm{~cm}$} & \multicolumn{4}{|c|}{ Soil layer $15-30 \mathrm{~cm}$} \\
\hline & & $\mathbf{F e}$ & Mn & $\mathbf{P b}$ & $\mathbf{N i}$ & $\mathbf{F e}$ & Mn & $\mathbf{P b}$ & $\mathbf{N i}$ \\
\hline \multirow[t]{3}{*}{$\overline{\mathbf{A}}$} & Clay & 1.28 & 1.08 & 1.52 & 1.50 & 1.25 & 1.12 & 1.55 & 1.59 \\
\hline & Silt & 1.00 & 1.10 & 0.79 & $\mathbf{0 . 8 3}$ & 1.01 & 1.00 & 0.79 & 0.78 \\
\hline & Sand & 0.42 & 0.71 & 0.24 & 0.23 & 0.43 & 0.69 & 0.23 & 0.21 \\
\hline \multirow[t]{3}{*}{ B } & Clay & 1.37 & 0.40 & 1.63 & 1.47 & 1.31 & 0.3 & 1.57 & 1.47 \\
\hline & Silt & 1.18 & 1.67 & 1.24 & 1.33 & 1.18 & 1.48 & 1.28 & 1.31 \\
\hline & Sand & 0.48 & 0.98 & 0.11 & 0.20 & 0.48 & 1.18 & 0.96 & 0.17 \\
\hline \multirow[t]{3}{*}{ C } & Clay & 1.13 & 0.7 & 1.20 & 1.50 & 1.06 & 0.8 & 1.24 & 1.12 \\
\hline & Silt & 0.94 & 0.91 & 1.31 & 0.64 & 0.98 & 0.94 & 0.79 & 0.99 \\
\hline & Sand & 0.77 & 2.08 & 0.14 & 0.11 & 0.66 & 2.59 & 0.13 & 0.18 \\
\hline \multirow[t]{3}{*}{ D } & Clay & $\mathbf{1 . 0 7}$ & 0.8 & 1.04 & 1.13 & 1.04 & 0.90 & 1.06 & 1.12 \\
\hline & Silt & 0.94 & 0.91 & 1.10 & 0.83 & 1.02 & 1.00 & 1.04 & 0.83 \\
\hline & Sand & 0.47 & 1.78 & 0.06 & 0.15 & 0.42 & 2.02 & 0.06 & 0.16 \\
\hline \multirow[t]{3}{*}{$\mathbf{E}$} & Clay & 1.14 & 0.5 & 1.61 & 1.7 & 1.13 & 0.6 & 1.38 & 1.32 \\
\hline & Silt & 1.07 & 0.96 & 1.11 & 0.93 & 1.05 & 0.8 & 1.28 & 1.27 \\
\hline & Sand & 0.72 & 1.73 & 0.06 & 0.15 & 0.43 & 1.91 & 0.05 & 0.18 \\
\hline \multirow[t]{3}{*}{$\mathbf{F}$} & Clay & 1.22 & 0.7 & 1.36 & 1.39 & 1.22 & 0.7 & 1.36 & 1.39 \\
\hline & Silt & 1.06 & 0.85 & 1.16 & 1.06 & 1.00 & 0.9 & 1.11 & 1.06 \\
\hline & Sand & 0.48 & 1.58 & 0.09 & 0.14 & 0.56 & 1.75 & 0.09 & 0.13 \\
\hline \multirow[t]{3}{*}{ G } & Clay & 1.25 & 0.90 & 1.65 & 1.66 & 1.28 & 0.7 & 1.56 & 1.69 \\
\hline & Silt & 1.05 & 0.87 & 1.00 & 1.10 & 1.09 & 1.15 & 1.06 & 1.01 \\
\hline & sand & 0.69 & 1.26 & 0.56 & 0.25 & 0.63 & 1.12 & 0.40 & 0.28 \\
\hline
\end{tabular}

\section{REFERENCES :}

1- Forstner, U. (1991) Soil pollution phenomena-mobility of heavy metals in contaminated soil, in Bolt. Et al., (eds.) "Interactions at the soil colloid-soil solution interface" Kluwer Academic Pub. PP.203-335.

2- Abdel-Kareim, A.M.M. (1995) Chemical analysis and mineralogical characteristics of soil and their significance on fertility variation of soil in Monofia Governerate, M.Sc. Thesis, Faculty of Sci., Monefia Univ., Egypt.
3- Rabie, F. Rashad, I.F.; Khadr, M. Y.; and Hussein, W. (1996): Contents of biogenic and non biogenic heavy metals in El-Saff soils as related to different pollution sources, Egypt. J. Soil Sci. 36: 165 - 177.

4- Alloway, B.J. (1995) (ed.) "Heavy Metals in Soils" Blackie Academic and Professional, UK.

5- Rashad, I. F.; Abdel Nabi， A.O.; ElHemely, M.E.; Khalaf, M.A. (1995): Background levels of heavy metals in the 
Nile Delta soils, Egypt. J. Soil Sci. 35: 239252.

6- El-Leithi, A.A. (1986) pedological studies of heavy metals in the vicinity of some industrial and highway areas in soil of Nile Delate, Ph.D. Thesis, Faculty of Agric. Alex. Univ., Egypt.

7- El-Sebaay, M.M. (1995) Studies on chemical pollution of different waters with some heavy metals in Fayoum Governorate, M.Sc Thesis, Fact. of Agric. Moshtohor, Zagazig Univ. Egypt.

8- Nriagu, J.O.C. (1971). (ed.) "The Biogechemistry of lead in the Environment" Elsever, North Holand.

9- Davies, B. E. (1980): Applied Soil Trace Elements, New York. John Wiley \& Sons LTd. New York.

10-El-Sabbagh, T. A. (1991): Environmental impact of industrial area "Mostorod" on the concentrations of some elements in water, soil and plant. M. Sc. Thesis, Institute of Environmental Studies and Research, Ain Shams Univ. Egypt.

11- Ramadan, M.A. (1995): " Studies on the pollution of the agricultural environment in Egypt" Ph.D. Thesis, Fac. of Agric., Cairo Univ., Egypt.

12- El-Sayed, E. A. and Hegazy, M. N. A. (1993): Total contents and extractable amounts of $\mathrm{Cd}, \mathrm{Co}, \mathrm{Cr}$ and $\mathrm{Ni}$ in some soils of El-Fayoum Govern. Egyptian Fayoum J. of Agric. Resh. And Develop. 7: 46-56.

13- Laveady， J. (1974): "Methods for Analysis of Irrigated Soils" CAG Fornham Royaal. Rucks, England.

14- Jackson， M.L. (1969) "Soil Chemical
Analysis" Advanced course, publish by author, Dept. of Soils, Univ. of MadisonWisconsin, USA.

15- Abdel-Sabour, M.F.; Rabie, F.H.; Mostfa, T. and Hassan, S.A. (1998) Impact of industrial wastewater disposal on surface water bodies in industrial area north Greater Cairo, Paper represented in $4^{\text {th }}$ International Conference on the Environmental Geo-technology and Global Sustainable Development, Aug. 913, Boston, Massachusetts, USA.

16- Abdel-Sabour, M.F. and Rabie, F.H. (1999) Heavy metals contamination in fresh water canals at industrial area north Greater Cairo, Egypt Soil Sci. J. (in press).

17- El-Toukhy，M.M.A. (1995). Studies on land evaluation and land use of some soils in North Delta, Ph.D. Thesis Fact. of Agric. Zagazig Univ. Egypt.

18- Childs, C.W. (1975) Composition of iron-manganese concentrations from some New Zealand soils, Geoderma 131:141-152.

19- Nair, K. P. P. and Cottenie, A. (1971): "Trace Element Pollution" In Applied Soil Trace Elements; Davies, B. E. (ed). P. 206223, New York. John Wiley \& Sons LTd.

20- Rabie, F.H.; M. F. Abdel-Sabour, A. T. Mostafa, S. A. Hassan, (1997) Enrichment factor of heavy metals in different soil grain size fractions as an indicator for soil pollution, Paper represented in $4^{\text {th }}$ International Conference on the Environmental Geo-technology and Global Sustainable Development, Aug. 9-13, Boston, Massachusetts, USA.

21- Andersson, A. (1979): On the 
distribution of heavy metals as compared to some other elements between grain size fractions in soils. Swedish J. Agric. Res., 9: 7-

13.

در اسة تر اكم الحديد والمنجنيز والرصاص على التربة وعلى نسب معامل الإثراء فى مختلف حبيبات التربة كدليل على التلوث

$$
\begin{aligned}
& \text { فريدة حسن ربيع " وممدوح فتحى عبد الصبور** } \\
& \text { * جامعة عين شمس ـ كلية الزر اعة ـ القاهرة . } \\
& \text { ** مركز البحوث النووية ـ هيئة الطاقة النووية ــ القاهرة }
\end{aligned}
$$

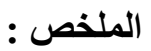

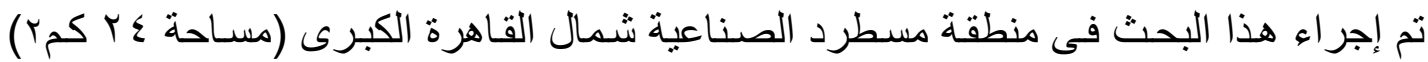

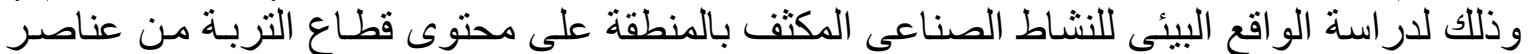

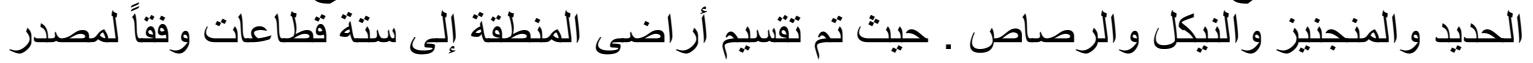

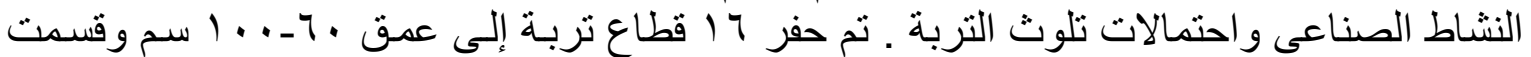

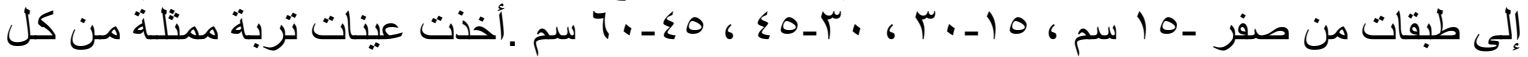

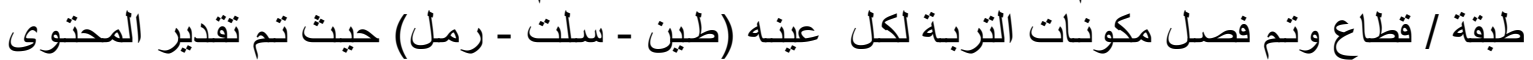

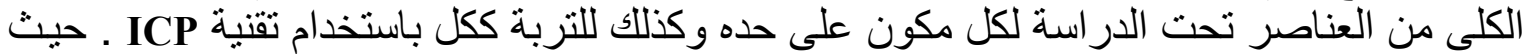

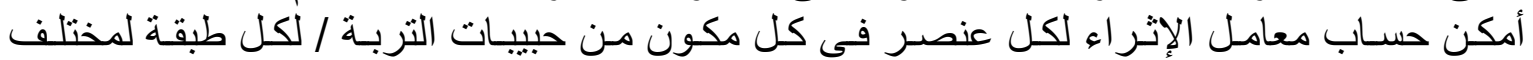

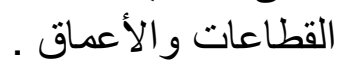

أوضحت النتائج أن أعلى قيمة لمعامل الإثراء كانت في حالة الرصاص في حبيبات الطين مدا

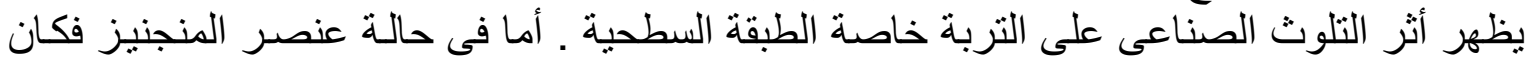

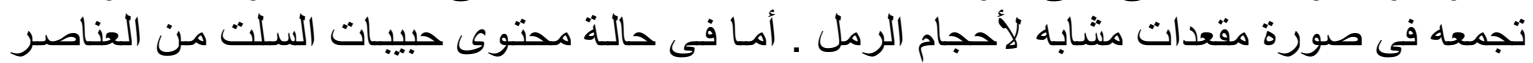

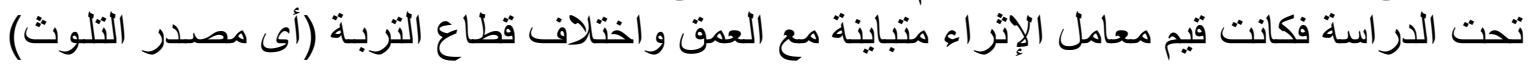

